\title{
Germination and Seedling Development of Seeds from Different Parkia biglobosa (Jacq) G. Don Trees
}

\author{
Christiana O. ADEYEMI ${ }^{*}$, Kehinde S. OLORUNMAIYE², \\ Elizabeth O. ORHUAMEN² ${ }^{2}$ Kike O. OGUNSOLA² \\ ${ }^{1}$ Kwara State University, College of Pure and Applied Sciences, Department of Biosciences and Biotechnology, \\ P.M.B 5320, Malete, Ilorin, Kwara State, Nigeria; oreadeyemi@yahoo.com (*corresponding author) \\ ${ }^{2}$ University of Ilorin, Faculty of Science, Department of Plant Biology, P.M.B 1515, Ilorin, Kwara State, Nigeria
}

\begin{abstract}
The effect of daylight, continuous illumination and acid scarification on the seed germination and seedling vegetative growth (epicotyl and hypocotyl lengths, and number of secondary roots) of different Parkia biglobosa were investigated in the Plant Physiology Laboratory University of Ilorin, Ilorin Kwara State Nigeria. Seeds from two out of the twenty six Parkia tree samples (trees B and T) germinated within 24 hours of planting in the daylight germination study while seeds from another tree (Q) did not germinate until the third week after planting (3WAP). Some seeds have higher germination percentage both in the daylight (preliminary germination study) and in the continuous light (illuminated study). The treatment with concentrated Sulphric acid (conc. $\left.\mathrm{H}_{2} \mathrm{SO}_{4}\right)$ was effective in breaking the seed dormancy as seeds from eight (8) trees produced one hundred percent (100\%) germination. At $p=0.05$ the length of epicotyl and hypocotyl lengths were significantly different as seedling vegetative growth were long in the seedlings from the daylight experiment than the continuous light experiment. The vegetative growths of the seedlings from the scarified seed were longer at $15 \mathrm{~min}$ of scarification in all except in trees $\mathrm{F}$ and $\mathrm{Z}$. It was observed that the time of scarification affect the both seed germination and seedling development.
\end{abstract}

Keywords: acid scarification, continuous illumination, daylight, epicotyl lengths, hypocotyl lengths, seed germination, seedling vegetative growth

\section{Introduction}

Many seeds are insensitive to light, but in a number of species germination is stimulated or inhibited by exposure to continuous or short periods of illumination such seeds are referred to as photoblastic. Corn (maize), the smaller cereals, and many legumes, such as beans and clover, germinate in light as well as in darkness. Inhibition by light is found in chive, garlic, and several other species of the lily family, jimson weed, fennel flower (Nigella), Phacelia, Nemophila, and pigweed (Amaranthus). Certain kinds of seeds require light for germination, while other apparently have no requirement. It has been reported that germination of many seeds were clearly development by the action of phytochrome, but such action was found to be absent or not obvious in others. Temperature and light are important factors affecting germination and seedling growth of some seed plants (Encyclopaedia Britannica, 2011). Growth of autotrophic plants is directly and dramatically influenced by light intensity (i.e. quantum flux density) which is the driving force of photosynthesis and provides nearly all of the carbon and chemical energy needed for plant growth (Akhter, 2009).The dormancy in seeds is usually associated with the factors of protective covering the seed coats or the enclosed embryo. From the investigation carried out by Aliero (2004), treatment with wet heat and subsequent soaking in water, mechanical scarification and application of sulphuric acid were found to induce germination of the seed of Parkia. According to Levitt (1974), immersion of seed in highest concentrated sulphuric acid disrupts the seed coat. Sulphuric acid disrupt the seed coat and expose the lumens of the macrosclereids cells permitting imbibitions of water (Nikoleave, 1977) which triggers germination. Sudden dip of dry seeds in boiling water may lead to the rapture of the seed coat wall allowing water to permeate the seed tissues causing physiological changes and subsequent germination of the embryo (Agboola and Etejere, 1991; Agboola and Adedire, 1998; Sabongari, 2001).

\section{Materials and methods}

The effect of different periods of light and acid scarification on the seed germination and seedling development of twenty-six selected Parkia biglobosa were tested in this research. The germination count, epicotyl (plumule) and hypocotyl (radicle) lengths as well as the number of secondary root were the factors taken into consideration, measured and recorded. 


\section{Collection of samples}

The fruits of the P. biglobosa were collected from twenty-six different trees in April 2010 during the harvesting period at the permanent site of the University of Ilorin, Ilorin, $\left(8.32^{\circ} \mathrm{N}\right.$ and $\left.4.34^{\circ} \mathrm{E}\right)$ Kwara State, Nigeria.

The fruits after harvesting were packed in bunches and labeled according to the trees which collections were made from as tree A, B, C, D, E ... to tree Z.

The outer shells or husks (Hall et al., 1997) of the pods, the dry brown indehiscent pods (Sacande and Clethero, 2007) were opened along the suture manually to remove the seeds together with the yellow pulp. The pulps were washed off from the seeds in a big plastic sieve in water. The seeds were separated after several changes of water. The seeds were sorted through floating method, sun-dried and packed in air tight transparent polythene bag, labeled and stored in a dry cool place.

The pulps were thoroughly washed away from the seeds because they germinated better when clean as reported by Sacande and Clethero (2007).

\section{Study site}

The research work was carried out in the Plant Physiology Laboratory at the Department of Plant Biology, University of Ilorin, Ilorin, Kwara State, Nigeria.

\section{Materials used}

The materials used were Petri-dishes, serviette paper, water, Measuring cylinder, Funnel, Plastic sieve, Polythene bags, Scissors. The serviette papers were trimmed to the size of the Petri-dishes with a pair of scissors, which served as the planting medium and placed in each of the Petridishes.

Experiment 1: Effect of daylight on seed germination and seedling development

The daylight germination study was done by planting seeds from the various Parkia trees sample under the normal daylight to determine the intensity of the light on the germination of the seeds.

Five (5) seeds each from the twenty-six trees of Parkia biglobosa were planted in already prepared Petri-dishes previously lined with serviette paper soaked with $2 \mathrm{ml}$ of water. The Petri-dishes were placed in aerated Plant Physiology Laboratory at room temperature and three replications were allocated for each tree.

Experiment 2: Effect of continuous lighting on seed germination and seedling development

A similar experiment was setup but kept in an illuminator at temperature range of $26-28^{\circ} \mathrm{C}$. Two $\mathrm{ml}$ of water was added to the plant once in three days to moisten the serviette paper used as medium for planting.

Experiment 3: Effect of acid scarification on seed germination and seedling development

After the daylight germination test and the continuous light experiments, Acid scarification was carried out on some of the seeds of the Parkia biglobosa that were ob- served to have exhibited seed coat dormancy. Seeds from eleven trees from the twenty six samples were treated with concentrated sulphuric acid $\left(\mathrm{H}_{2} \mathrm{SO}_{4}\right)$ at different periods to cause degradation of the seed coat. This was done in the period of 5,10 and 15minutes respectively. After the scarification, the seeds were thoroughly washed with several changes of water to stop the reaction of the concentrated sulphuric acid on the seed coat in order to prevent over scarification which may cause reduction in germination. Five scarified seeds were planted in Petri-dish previously lined with serviette paper soaked with $2 \mathrm{ml}$ of water in three replicates. Germination count was taken daily while epicotyl (plumule) and hypocotyl (Radicle) lengths, and number of roots were taken weekly using the method of Olorunmaiye et al. (2004) and Ayisire et al. (1997) for all the experiment and were observed within three weeks.

\section{Experiment design and data analysis}

In determining the effect of the different period of light on the seed germination and seedling vegetative growth of the twenty-six Parkia biglobosa samples data Analysis was done through analysis of variance (ANOVA) using SPSS package at 5\% level of significance. The Duncan Multiple Range Test (DMRT) was used to separate the means.

\section{Results and discussion}

The results of the experiments carried out on the twenty six different samples of $P$. biglobosa shows variations in seed germination and seedling vegetative growth characteristics.

Seed germination in tree $\mathrm{B}$ and $\mathrm{T}$ was observed to be highest in the first week of planting for the daylight experiment while the highest seed germination $\%$ was observed only in tree $\mathrm{T}$ for the continuous light experiment ( Tab. 1). Tree A and B have 50\% seed germination for both daylight and cont. light experiment at the first week of planting. Seeds which were observed to have prolonged seed germination were subjected to acid scarification to check if the dormancy observed was due to seed coat. These seeds were scarified by the application of concentrated sulphuric acid for varying period of 5,10 and 15 minutes. The treatment with concentrated Sulphuric acid (conc. $\mathrm{H}_{2} \mathrm{SO}_{4}$ ) was effective in breaking the seed dormancy as seeds from eight trees (F, I, L, Q, R, S, Y and Z) out of the eleven trees scarified produces $100 \%$ seed germination count at 15 minutes of scarification. Seven trees (F, I, L, Q, S, Y and $\mathrm{Z}$ ) produces $100 \%$ seed germination at 10 minutes of acid scarification (Fig. 1). The result of the seed germination in the Daylight (Preliminary) experiment shows that seeds from some Parkia trees among the sample germinated without pre-treating with chemical scarification whereas some did not germinate until they were pretreated. The differences in the seed germination among the twenty six selected Parkia samples can be attributed to the nature of the seeds of P. biglobosa; as two types were observed, one 
122

with brown colour seed coat and the other with a darkblack colour seed coat. This agrees with the observation of Hopkins (1983) and Olorunmaiye et al. (2011). The seeds with brown seed coat germinated earlier than the dark-black, which suggests easier water penetration by the former and required no pretreatment of seeds. Germination of seeds and vegetative growth of the continuous light experiment shows that some seeds were light sensitive which is in agreement with the reports of Akhteret et al. (2009), Singh (1997), and Huang et al. (1993) while some are not light sensitive (Khan and Rizvi, 1994). The sensitive of seeds observed in trees $\mathrm{C}, \mathrm{I}$ and V in the illuminated germination studies have their seed germination higher than that of the daylight germination studies at 3 WAP. This result also greed with the reports of Khan and Ungar (1999), Andrews (1997) and Garcia et al. (1995). These differences in the intensity of light might be due to variation in the amount of light needed by seeds to germinate with. Some seeds required considerable sunlight and others germinate only in complete darkness. The results in Fig. 1, 2, 3 and Tab. 5 from different scarification time on the seed of some of the Parkia tree samples shows that $P$. biglobosa seeds treated, germinated faster. This agreed with the report of Sucande and Clethero (2007). The treatment with concentrated sulphuric acid was observed to be ef- fective in breaking the seed dormancy of $P$. biglobosa as its dormancy was associated with the factor of the protective covering; the seed coats. From this investigation, treatment with the application of sulphuric acid was found to induce germination of seeds of the Parkia trees as almost all the seeds scarified at 15 minutes of application of sulphuric acid germinated. This agrees with the reports of Olorunmaiye et al. (2004), Agboola (1998), Agboola and Etejere (1991). Generally, scarification for 15 minutes seems to be the best method for breaking the seed dormancy in $P$. biglobosa. From the above, one can infer that dormancy of Parkia was probably associated with the seed coat (Etejere et al., 1982), since the treatment that induced germination were those that can effect disruption of the seed coat. According to Levitt (1974) immersion of seed in high concentrated sulphuric acid disrupts the seed coat. The high \% germination observed at $15 \mathrm{~min}$ of acid scarification indicates that the more the seed coat is ruptured the faster the rate of germination (Aliero, 2004). This will expose the lumens of the macroscereids cells and permit imbibitions of water (Nikoleave, 1977) which triggers germination.

The daylight experiment encourages the elongation of the epicotyl length of some seedlings as recorded in seedlings of tree $\mathrm{D}\left(5.55^{\mathrm{a}}\right)$ and $\mathrm{T}\left(5.16^{\mathrm{a}}\right)$ at the first week. The high rate of epicotyl lengthen in some of the seedlings was

Tab. 1.\% germination from the effect of different period of light on the of P. biglobosa seed

\begin{tabular}{|c|c|c|c|c|c|c|}
\hline \multirow{2}{*}{ Trees } & \multicolumn{2}{|c|}{ Week 1} & \multicolumn{2}{|c|}{ Week 2} & \multicolumn{2}{|c|}{ Week 3} \\
\hline & Daylight & Cont. light & Daylight & Cont. light & Daylight & Cont. light \\
\hline A & 50 & 20 & 30 & 0 & 13 & 0 \\
\hline B & 90 & 50 & 0 & 0 & 0 & 0 \\
\hline $\mathrm{C}$ & 7 & 3 & 7 & 13 & 10 & 0 \\
\hline $\mathrm{D}$ & 23 & 7 & 30 & 13 & 13 & 23 \\
\hline $\mathrm{E}$ & 20 & 17 & 67 & 23 & 7 & 7 \\
\hline $\mathrm{F}$ & 7 & 7 & 37 & 0 & 20 & 0 \\
\hline G & 7 & 27 & 17 & 7 & 7 & 0 \\
\hline $\mathrm{H}$ & 27 & 30 & 23 & 27 & 23 & 10 \\
\hline I & 7 & 37 & 37 & 13 & 13 & 13 \\
\hline $\mathrm{J}$ & 3 & 0 & 23 & 17 & 0 & 7 \\
\hline $\mathrm{K}$ & 20 & 17 & 37 & 47 & 23 & 7 \\
\hline $\mathrm{L}$ & 13 & 10 & 20 & 27 & 17 & 27 \\
\hline M & 23 & 17 & 57 & 23 & 13 & 17 \\
\hline $\mathrm{N}$ & 40 & 47 & 47 & 20 & 3 & 0 \\
\hline $\mathrm{O}$ & 23 & 17 & 27 & 17 & 7 & 10 \\
\hline $\mathrm{P}$ & 40 & 57 & 27 & 7 & 10 & 10 \\
\hline $\mathrm{Q}$ & 0 & 0 & 3 & 0 & 13 & 7 \\
\hline $\mathrm{R}$ & 7 & 13 & 33 & 7 & 3 & 0 \\
\hline$S$ & 10 & 7 & 10 & 3 & 17 & 3 \\
\hline $\mathrm{T}$ & 93 & 87 & 0 & 3 & 0 & 0 \\
\hline $\mathrm{U}$ & 23 & 30 & 50 & 20 & 7 & 10 \\
\hline V & 47 & 50 & 30 & 37 & 3 & 0 \\
\hline W & 30 & 47 & 47 & 10 & 3 & 10 \\
\hline$X$ & 17 & 20 & 37 & 23 & 13 & 7 \\
\hline $\mathrm{Y}$ & 30 & 37 & 30 & 0 & 10 & 0 \\
\hline $\mathrm{Z}$ & 10 & 13 & 43 & 3 & 7 & 0 \\
\hline
\end{tabular}




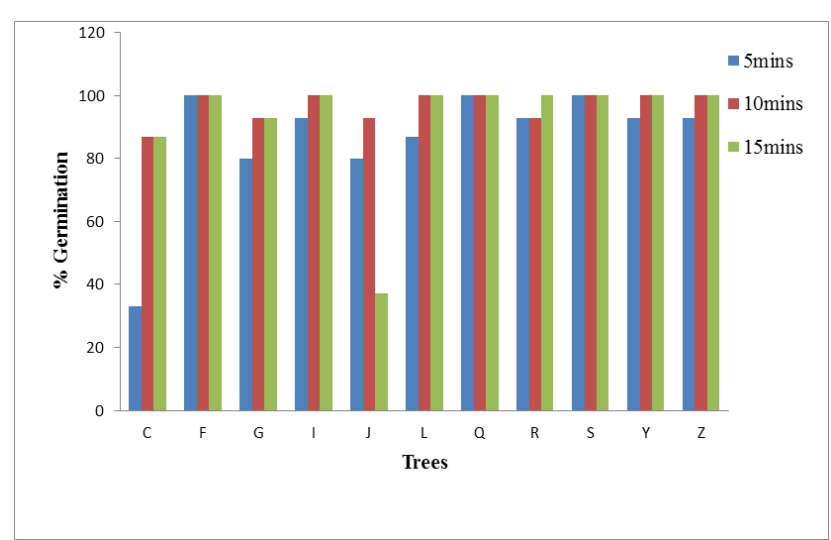

Fig. 1. \% germination from effect of different time of sulphuric acid scarification on the seed of some P. biglobosa samples observed in the continuous light. The time of exposure of the seedlings of tree $\mathrm{H}, \mathrm{K}, \mathrm{L}, \mathrm{P}, \mathrm{S}, \mathrm{U}, \mathrm{W}$ and $\mathrm{X}$ increases the rate of epicotyl growth for the period of the experiment
123

(Three weeks) in the continuous light compared with the daylight (Tab. 2). There was no epicotyl developments in seedlings of tree $\mathrm{Q}$ for both experiments throughout the three weeks as seed germination was only observed at the third week whereas seedlings of tree F has no epicotyl development in the continuous light experiment only.

For the hypocotyl length, majority of the seedlings in the continuous light experiment at first week have no hypcotyl development except in tree X, having $15.22^{a}$ which was the highest length recorded in both experiments followed by tree P. It was observed that in tree Q, due to its late seed germination has neither epicotyl length nor hypocotyl length (Tab. 3). Seedlings in trees A, B, C and F have no hypocotyl elongation in continuous light experiment.

Comparing the hypocotyl elongation in the two experiments, the continuous light encourages seedling vegetative growth with time of exposure in some tree samples, the

Tab. 2. The effect of different period of light on the epicotyl length $(\mathrm{cm})$ of seedlings $P$. biglobosa

\begin{tabular}{|c|c|c|c|c|c|c|}
\hline \multirow{2}{*}{ Trees } & \multicolumn{2}{|c|}{ Week 1} & \multicolumn{2}{|c|}{ Week 2} & \multicolumn{2}{|c|}{ Week 3} \\
\hline & Daylight & Cont. light & Daylight & Cont. light & Daylight & Cont. light \\
\hline A & $4.01^{-a c c}$ & $3.10^{a-d}$ & $5.06^{a-c}$ & $3.10^{\mathrm{cff}}$ & $7.76^{\mathrm{ab}}$ & $3.10^{d-g}$ \\
\hline B & $4.70^{\mathrm{ab}}$ & $0.00^{\mathrm{g}}$ & $4.70^{a-c}$ & $0.00^{\mathrm{f}}$ & $4.70^{a-d}$ & $0.00^{g}$ \\
\hline $\mathrm{C}$ & $0.00^{c}$ & $0.00^{\mathrm{g}}$ & $0.00^{c}$ & $0.00^{\mathrm{f}}$ & $1.28^{\mathrm{cd}}$ & $0.00^{\mathrm{g}}$ \\
\hline $\mathrm{D}$ & $5.55^{\mathrm{a}}$ & $0.47^{g}$ & $6.37^{\mathrm{ab}}$ & $1.25^{\mathrm{cf}}$ & $8.18^{\mathrm{ab}}$ & $5.72^{a-g}$ \\
\hline E & $1.75^{\mathrm{a}-\mathrm{c}}$ & $0.00^{\mathrm{g}}$ & $2.38^{\mathrm{acc}}$ & $1.70^{\mathrm{cf}}$ & $5.12^{a-d}$ & $2.61^{\mathrm{c}-\mathrm{g}}$ \\
\hline $\mathrm{F}$ & $1.43^{a-c}$ & $0.00^{\mathrm{g}}$ & $1.43^{\mathrm{bc}}$ & $0.00^{\mathrm{f}}$ & $3.95^{\mathrm{a-d}}$ & $0.00^{\mathrm{g}}$ \\
\hline G & $2.89^{a-c}$ & $0.90^{c-g}$ & $3.59^{a-c}$ & $2.10^{\mathrm{cf}}$ & $5.09^{a-d}$ & $2.10^{\mathrm{fg}}$ \\
\hline $\mathrm{H}$ & $2.57^{a-c}$ & $1.22^{\mathrm{d}-\mathrm{g}}$ & $3.62^{a-c}$ & $3.28^{\mathrm{cff}}$ & $6.05^{-a-c}$ & $10.36^{a-c}$ \\
\hline I & $2.93^{a-c}$ & $2.86^{\mathrm{a}-\mathrm{d}}$ & $3.40^{a-c}$ & $6.68^{a-c}$ & $7.27^{a-c}$ & $9.19^{a-d}$ \\
\hline $\mathrm{J}$ & $2.00^{a-c}$ & $0.00^{\mathrm{g}}$ & $2.00^{\mathrm{bc}}$ & $0.00^{\mathrm{f}}$ & $2.92^{\mathrm{b}-\mathrm{d}}$ & $1.03^{\mathrm{fg}}$ \\
\hline $\mathrm{K}$ & $4.77^{\mathrm{ab}}$ & $1.17^{\mathrm{d}-\mathrm{g}}$ & $6.00^{\mathrm{ab}}$ & $4.52^{\mathrm{b}-\mathrm{c}}$ & $8.43^{\mathrm{ab}}$ & $8.66^{a-c}$ \\
\hline $\mathrm{L}$ & $1.63^{a-c}$ & $0.00^{\mathrm{g}}$ & $2.50^{a-c}$ & $3.86^{\mathrm{b}-\mathrm{f}}$ & $6.45^{-a-c}$ & $6.84^{a-f}$ \\
\hline M & $4.70^{\mathrm{ab}}$ & $0.65^{\mathrm{fg}}$ & $5.80^{\mathrm{ab}}$ & $3.53^{b-f}$ & $9.23^{\mathrm{a}}$ & $4.59^{c-g}$ \\
\hline $\mathrm{N}$ & $2.48^{a-c}$ & $2.45^{\mathrm{c}-\mathrm{f}}$ & $4.79^{a-c}$ & $4.39^{\mathrm{b}-\mathrm{c}}$ & $8.30^{\mathrm{ab}}$ & $5.14^{a-g}$ \\
\hline $\mathrm{O}$ & $2.20^{a-c}$ & $1.72^{\mathrm{c-g}}$ & $4.00^{a-c}$ & $4.57^{\mathrm{b}-\mathrm{c}}$ & $6.39^{a-c}$ & $6.93^{\mathrm{a}-\mathrm{f}}$ \\
\hline $\mathrm{P}$ & $4.13^{3-c}$ & $4.62^{\mathrm{a}}$ & $6.15^{\mathrm{ab}}$ & $7.05^{-a c}$ & $7.89^{\mathrm{ab}}$ & $10.87^{\mathrm{ab}}$ \\
\hline Q & $0.00^{c}$ & $0.00^{g}$ & $0.00^{c}$ & $0.00^{\mathrm{f}}$ & $0.00^{\mathrm{d}}$ & $0.00^{\mathrm{g}}$ \\
\hline $\mathrm{R}$ & $3.30^{a-c}$ & $3.47^{a-c}$ & $4.62^{2-c}$ & $4.73^{\mathrm{b}-\mathrm{c}}$ & $6.31^{a-c}$ & $4.73^{b-g}$ \\
\hline S & $4.10^{a-c}$ & $2.77^{a-c}$ & $4.27^{-a-c}$ & $4.47^{\mathrm{b}-\mathrm{c}}$ & $4.60^{a-d}$ & $7.20^{\mathrm{a}-\mathrm{f}}$ \\
\hline $\mathrm{T}$ & $5.16^{a}$ & $2.74^{a-c}$ & $7.56^{\mathrm{a}}$ & $2.74^{\mathrm{c}-\mathrm{f}}$ & $7.56^{\mathrm{ab}}$ & $2.74^{\mathrm{c}-\mathrm{g}}$ \\
\hline $\mathrm{U}$ & $3.23^{a-c}$ & $0.62^{\mathrm{fg}}$ & $4.23^{-a c}$ & $3.25^{\mathrm{cf} f}$ & $6.01^{a-c}$ & $6.47^{a-g}$ \\
\hline $\mathrm{V}$ & $1.27^{a-c}$ & $1.75^{\mathrm{cg} g}$ & $3.92^{a-c}$ & $4.19^{b-f}$ & $7.20^{a-c}$ & $4.19^{c-g}$ \\
\hline W & $1.43^{a-c}$ & $3.78^{a b}$ & $4.19^{a-c}$ & $8.88^{\mathrm{a}}$ & $6.76^{-\mathrm{ac}}$ & $11.17^{\mathrm{a}}$ \\
\hline X & $4.87^{\mathrm{ab}}$ & $3.76^{\mathrm{ab}}$ & $5.52^{\mathrm{ab}}$ & $7.81^{\mathrm{ab}}$ & $7.91^{\mathrm{ab}}$ & $10.11^{a-c}$ \\
\hline $\mathrm{Y}$ & $0.72^{\mathrm{bc}}$ & $2.53^{\mathrm{c}-\mathrm{f}}$ & $3.34^{a-c}$ & $2.53^{\mathrm{d}-\mathrm{f}}$ & $5.09^{a-d}$ & $2.53^{\mathrm{c-g}}$ \\
\hline $\mathrm{Z}$ & $0.00^{c}$ & $0.88^{\mathrm{cg} g}$ & $1.85^{\mathrm{bc}}$ & $3.55^{\mathrm{b}-\mathrm{f}}$ & $4.51^{a-d}$ & $3.55^{\mathrm{d}-\mathrm{g}}$ \\
\hline
\end{tabular}

Values with the same letter(s) along the same column are not significantly different at $p=0.05$ 
124

daylight also supports some seedlings growth and while in some, the effects was not very visible. The reduction in the epicotyl and hypocotyl lengths, and the number of secondary roots in the continuous light (illuminated) studied and the daylight (preliminary) studied might be that the intensity of the light produced by the illuminator used in this experiment was more than what the seeds can tolerate, because P. biglobosa being a legume do well at reduced light level (Akhker et al., 2009) or because the continuous light produced by the illuminator did not give room for dark reaction to take place, that is, the synthesis of carbohydrates and regeneration of ribulose diphosphate (Calvin, 1961).

The time of acid scarification determines the seedling vegetative growth as the longest epicotyl length was recorded in seedlings of seeds scarified at 15 minutes, except in trees $F$ and $Z$, where the epicotyl lengths was more elongated at $10 \mathrm{~min}$ of scarification (Fig. 2). From Fig. 3, seedling of tree $\mathrm{C}$ has the shortest hypocotyl length at 5 min of application of concentrated sulphuric acid. Tree $\mathrm{H}$, $\mathrm{J}, \mathrm{Y}$ and $\mathrm{Z}$ seedlings have almost the same lengths at 10 and $15 \mathrm{~min}$. The hypocotyl length also increases with the varying period of scarification. Tree $\mathrm{F}$ has the same hypocotyl length in $5 \mathrm{~min}$ and $15 \mathrm{~min}$. Tree $\mathrm{C}$ was observed to have the shortest epicotyl and hypocotyl length at $5 \mathrm{~min}$ scarification (Fig. 3).

The secondary roots develop more in the daylight experiment. The highest number of secondary roots was observed in seedlings of tree $\mathrm{N}$ at the third week (Tab. 4) although a higher number of secondary roots were seen in seedling of tree $\mathrm{X}$ at the continuous light. Only seedlings of tree $\mathrm{K}$ has relatively same number of secondary roots in both experiments at the third week. The observation of the secondary roots number in the different time of scarification (Tab. 5) shows that all plants develop secondary root in different times except in plant $\mathrm{Z}$ at 10 min that has no secondary root.

Tab. 3. The effect of different period of light on the hypocotyl length $(\mathrm{cm})$ of seedlings $P$. biglobosa

\begin{tabular}{|c|c|c|c|c|c|c|}
\hline \multirow{2}{*}{ Trees } & \multicolumn{2}{|c|}{ Week 1} & \multicolumn{2}{|c|}{ Week 2} & \multicolumn{2}{|c|}{ Week 3} \\
\hline & Daylight & Cont. light & Daylight & Cont. light & Daylight & Cont. light \\
\hline A & $4.67^{a-d}$ & $2.27^{\mathrm{b}-\mathrm{g}}$ & $7.15^{\mathrm{ab}}$ & $2.27^{\mathrm{c}-\mathrm{g}}$ & $9.69^{a}$ & $2.27^{\mathrm{d}-\mathrm{f}}$ \\
\hline $\mathrm{B}$ & $5.21^{a-c}$ & $2.00^{\mathrm{g}}$ & $5.21^{a-d}$ & $0.00^{\mathrm{g}}$ & $5.21^{a-d}$ & $0.00^{f}$ \\
\hline $\mathrm{C}$ & $0.00^{c}$ & $2.00^{g}$ & $0.00^{c}$ & $0.00^{g}$ & $1.25^{\mathrm{cd}}$ & $0.00^{\mathrm{f}}$ \\
\hline $\mathrm{D}$ & $6.10^{a}$ & $0.53^{f g}$ & $7.55^{\mathrm{a}}$ & $1.68^{\mathrm{fg}}$ & $9.43^{a}$ & $5.77^{\mathrm{a}-\mathrm{f}}$ \\
\hline E & $3.17^{a-c}$ & $0.60^{\mathrm{fg}}$ & $4.22^{-a c}$ & $2.54^{\mathrm{d}-\mathrm{f}}$ & $7.00^{a-c}$ & $3.60^{\mathrm{cf}}$ \\
\hline F & $1.40^{c-c}$ & $2.00^{\mathrm{g}}$ & $1.40^{\mathrm{de}}$ & $0.00^{\mathrm{g}}$ & $4.10^{a-d}$ & $0.00^{\mathrm{f}}$ \\
\hline G & $1.07^{\mathrm{de}}$ & $0.90^{\mathrm{c}-\mathrm{g}}$ & $2.10^{c-c}$ & $1.68^{\mathrm{fg}}$ & $3.27^{\mathrm{b}-\mathrm{d}}$ & $1.98^{\mathrm{d}-\mathrm{f}}$ \\
\hline $\mathrm{H}$ & $3.87^{\mathrm{acc}}$ & $1.87^{\mathrm{cg} g}$ & $5.28^{a-c}$ & $4.11^{\mathrm{d}-\mathrm{g}}$ & $8.28^{\mathrm{ab}}$ & $8.28^{a-d}$ \\
\hline I & $3.33^{\mathrm{a}-\mathrm{c}}$ & $3.31^{\mathrm{a}-\mathrm{d}}$ & $3.92^{a-c}$ & $8.67^{a-c}$ & $8.70^{\mathrm{ab}}$ & $11.62^{\mathrm{a}}$ \\
\hline $\mathrm{J}$ & $2.30^{a-c}$ & $2.00^{\mathrm{g}}$ & $2.30^{\mathrm{b}-\mathrm{c}}$ & $0.00^{\mathrm{g}}$ & $3.14^{\mathrm{b}-\mathrm{d}}$ & $2.52^{\mathrm{d}-\mathrm{f}}$ \\
\hline $\mathrm{K}$ & $4.42^{a-d}$ & $1.87^{\mathrm{cg} g}$ & $5.47^{a-d}$ & $6.12^{\mathrm{a}-\mathrm{c}}$ & $8.17^{\mathrm{ab}}$ & $10.53^{\mathrm{ab}}$ \\
\hline $\mathrm{L}$ & $2.70^{a-c}$ & $2.00^{\mathrm{g}}$ & $3.55^{a-c}$ & $4.47^{\mathrm{c-f}}$ & $8.35^{\mathrm{ab}}$ & $6.95^{\mathrm{a-c}}$ \\
\hline M & $3.40^{a-c}$ & $0.86^{\mathrm{c}-\mathrm{g}}$ & $5.09^{a-d}$ & $3.48^{d-g}$ & $9.12^{\mathrm{ab}}$ & $5.66^{\mathrm{a}-\mathrm{f}}$ \\
\hline $\mathrm{N}$ & $3.16^{a-c}$ & $3.14^{a-c}$ & $5.16^{a-d}$ & $5.69^{\mathrm{a}-\mathrm{f}}$ & $9.09^{\mathrm{ab}}$ & $7.32^{a-d}$ \\
\hline $\mathrm{O}$ & $2,13^{b-c}$ & $3.40^{a-d}$ & $4.91^{a-d}$ & $5.95^{\mathrm{a}-\mathrm{f}}$ & $7.23^{a-c}$ & $9.33^{\mathrm{a}-\mathrm{c}}$ \\
\hline $\mathrm{P}$ & $3.90^{a-d}$ & $4.66^{\mathrm{a}}$ & $6.38^{\mathrm{a}-\mathrm{c}}$ & $6.81^{a-d}$ & $8.48^{\mathrm{ab}}$ & $10.19^{\mathrm{ab}}$ \\
\hline Q & $0.00^{c}$ & $2.00^{\mathrm{g}}$ & $0.00^{\mathrm{c}}$ & $0.00^{\mathrm{g}}$ & $0.00^{\mathrm{d}}$ & $0.67^{\mathrm{cf}}$ \\
\hline $\mathrm{R}$ & $4.20^{a-d}$ & $3.50^{a-d}$ & $6.26^{a-d}$ & $5.03^{b-f}$ & $8.49^{\mathrm{ab}}$ & $5.03^{b-f}$ \\
\hline$S$ & $3.00^{a-c}$ & $2.77^{\mathrm{a}-\mathrm{f}}$ & $3.50^{a-c}$ & $4.77^{\mathrm{b}-\mathrm{f}}$ & $4.25^{a-d}$ & $7.57^{\mathrm{a}-\mathrm{d}}$ \\
\hline $\mathrm{T}$ & $4.59^{a-d}$ & $3.28^{a-d}$ & $6.99^{a-c}$ & $3.28^{d-g}$ & $6.99^{a-c}$ & $3.28^{\mathrm{c}-\mathrm{f}}$ \\
\hline $\mathrm{U}$ & $3.62^{a-c}$ & $1.32^{\mathrm{d}-\mathrm{g}}$ & $4.72^{a-c}$ & $4.64^{\mathrm{c-f}}$ & $7.74^{\mathrm{ab}}$ & $7.54^{\mathrm{a}-\mathrm{d}}$ \\
\hline V & $2.53^{a-c}$ & $3.14^{-a c}$ & $5.93^{-a d}$ & $6.13^{a-c}$ & $9.13^{\mathrm{ab}}$ & $6.13^{\mathrm{af}}$ \\
\hline W & $2.40^{a-c}$ & $4.27^{\mathrm{ab}}$ & $5.78^{a-d}$ & $8.99^{\mathrm{ab}}$ & $8.72^{\mathrm{ab}}$ & $11.44^{\mathrm{a}}$ \\
\hline $\mathrm{X}$ & $6.00^{\mathrm{ab}}$ & $4.24^{a-c}$ & $7.35^{\mathrm{a}}$ & $9.40^{\mathrm{a}}$ & $9.97^{\mathrm{a}}$ & $11.75^{\mathrm{a}}$ \\
\hline $\mathrm{Y}$ & $0.92^{\mathrm{de}}$ & $2.48^{\mathrm{a}-\mathrm{f}}$ & $3.99^{a-c}$ & $2.48^{\mathrm{d}-\mathrm{g}}$ & $5.48^{a-d}$ & $2.48^{\mathrm{d}-\mathrm{f}}$ \\
\hline Z & $0.00^{c}$ & $1.83^{\mathrm{d}-\mathrm{g}}$ & $2.22^{\mathrm{b}-\mathrm{c}}$ & $4.23^{\mathrm{d}-\mathrm{g}}$ & $6.25^{a-c}$ & $4.23^{\mathrm{b}-\mathrm{f}}$ \\
\hline
\end{tabular}

Values with the same letter(s) along the same column are not significantly different at $p=0.05$ 


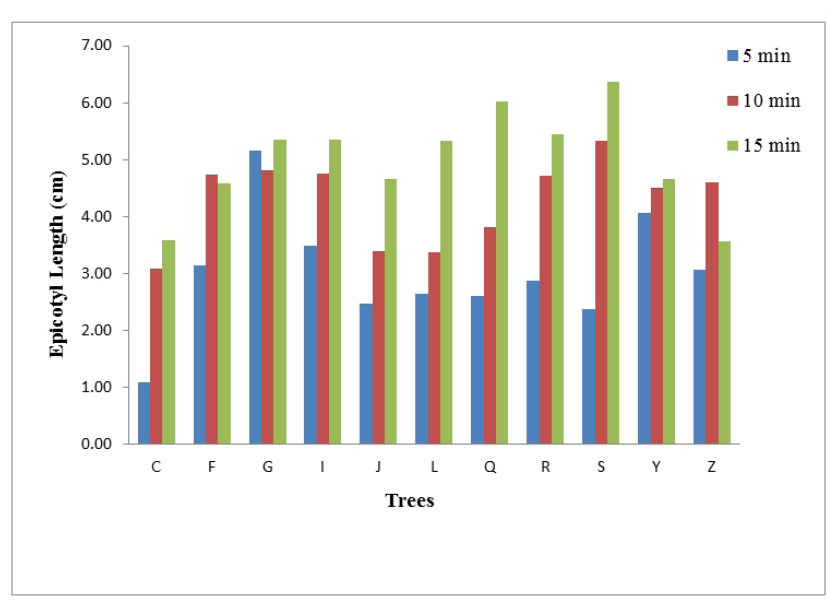

Fig. 2. Mean value of epicotyl length of seedlings of Parkia biglobosa samples from seeds scarification with sulphuric acid

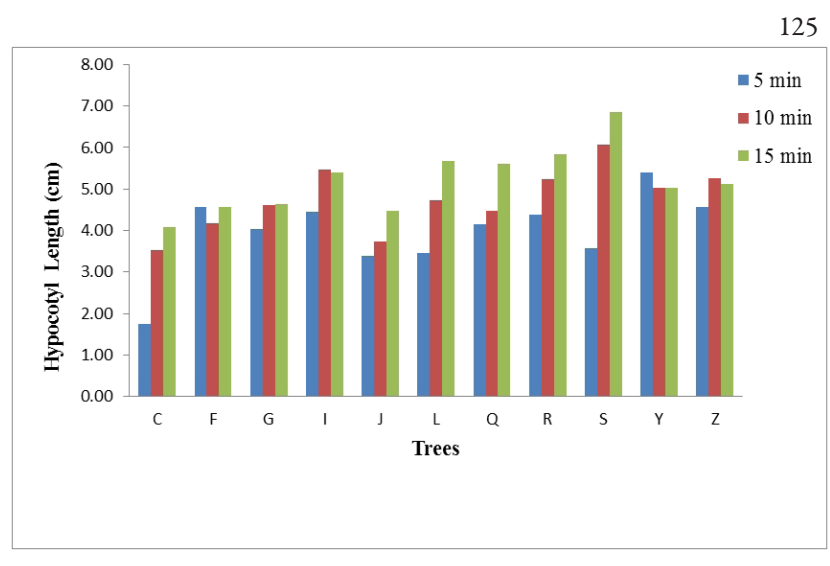

Fig. 3. Mean Value of Hypocotyl length of seedlings of Parkia biglobosa samples from seeds scarification with sulphuric acid

Tab. 4. The effect of different period of light on the secondary root of seedlings P. biglobosa

\begin{tabular}{|c|c|c|c|c|c|c|}
\hline \multirow{2}{*}{ Trees } & \multicolumn{2}{|c|}{ Week 1} & \multicolumn{2}{|c|}{ Week 2} & \multicolumn{2}{|c|}{ Week 3} \\
\hline & Daylight & Cont. light & Daylight & Cont. light & Daylight & Cont. light \\
\hline A & $4.67^{a-c}$ & $0.00^{\mathrm{d}}$ & $4.67^{\mathrm{ab}}$ & $0.00^{\mathrm{c}}$ & $10.00^{\mathrm{b}-\mathrm{d}}$ & $0.00^{f}$ \\
\hline $\mathrm{B}$ & $8.61^{a}$ & $0.00^{\mathrm{d}}$ & $8.61^{\mathrm{ab}}$ & $0.00^{\mathrm{c}}$ & $8.61^{b-d}$ & $0.00^{f}$ \\
\hline $\mathrm{C}$ & $0.00^{c}$ & $0.00^{\mathrm{d}}$ & $0.00^{\mathrm{b}}$ & $0.00^{\mathrm{c}}$ & $5.00^{\mathrm{cd}}$ & $0.00^{f}$ \\
\hline $\mathrm{D}$ & $8.17^{\mathrm{ab}}$ & $0.00^{\mathrm{d}}$ & $10.50^{\mathrm{ab}}$ & $3.00^{\mathrm{de}}$ & $21.50^{\mathrm{ab}}$ & $12.00^{a-f}$ \\
\hline $\mathrm{E}$ & $0.00^{c}$ & $0.00^{\mathrm{d}}$ & $0.00^{\mathrm{b}}$ & $2.11^{\mathrm{de}}$ & $5.00^{\mathrm{cd}}$ & $8.44^{\mathrm{b}-\mathrm{f}}$ \\
\hline $\mathrm{F}$ & $0.00^{c}$ & $0.00^{\mathrm{d}}$ & $0.00^{\mathrm{b}}$ & $0.00^{c}$ & $7.67^{b-d}$ & $0.00^{f}$ \\
\hline G & $0.00^{c}$ & $0.00^{\mathrm{d}}$ & $0.00^{\mathrm{b}}$ & $0.78^{\mathrm{c}}$ & $5.33^{\mathrm{cd}}$ & $0.78^{\mathrm{ef}}$ \\
\hline $\mathrm{H}$ & $4.89^{a-c}$ & $0.00^{\mathrm{d}}$ & $6.89^{\mathrm{ab}}$ & $5.50^{\mathrm{de}}$ & $12.89^{\mathrm{b}-\mathrm{d}}$ & $18.50^{\mathrm{a}-\mathrm{e}}$ \\
\hline I & $2.67^{a-c}$ & $1.22^{\mathrm{d}}$ & $2.67^{\mathrm{ab}}$ & $18.56^{\mathrm{bc}}$ & $4.17^{\mathrm{cd}}$ & $23.39^{a-c}$ \\
\hline $\mathrm{J}$ & $2.33^{a-c}$ & $0.00^{\mathrm{d}}$ & $2.33^{\mathrm{ab}}$ & $0.00^{\mathrm{c}}$ & $4.67^{\mathrm{cd}}$ & $3.33^{\mathrm{d}-\mathrm{f}}$ \\
\hline $\mathrm{K}$ & $9.50^{\mathrm{a}}$ & $0.00^{\mathrm{d}}$ & $13.00^{\mathrm{a}}$ & $10.42^{b-c}$ & $16.17^{b c}$ & $16.58^{a-f}$ \\
\hline $\mathrm{L}$ & $0.67^{\mathrm{bc}}$ & $0.00^{\mathrm{d}}$ & $3.67^{\mathrm{ab}}$ & $6.22^{\mathrm{de}}$ & $15.67^{\mathrm{b}-\mathrm{d}}$ & $12.44^{\mathrm{a}-\mathrm{f}}$ \\
\hline M & $0.00^{c}$ & $1.56^{\mathrm{cd}}$ & $9.17^{\mathrm{ab}}$ & $10.56^{\mathrm{b}-\mathrm{c}}$ & $16.33^{b c}$ & $14.89^{\mathrm{a}-\mathrm{f}}$ \\
\hline $\mathrm{N}$ & $5.67^{a-c}$ & $7.31^{b c}$ & $12.00^{\mathrm{ab}}$ & $10.97^{\mathrm{b}-\mathrm{c}}$ & $32.67^{a}$ & $11.97^{\mathrm{a}-\mathrm{f}}$ \\
\hline $\mathrm{O}$ & $0.00^{c}$ & $4.11^{\mathrm{b}-\mathrm{d}}$ & $2.83^{\mathrm{ab}}$ & $9.24^{\mathrm{b}-\mathrm{c}}$ & $6.50^{b-d}$ & $20.91^{\mathrm{a}-\mathrm{d}}$ \\
\hline $\mathrm{P}$ & $0.00^{c}$ & $9.54^{\mathrm{b}}$ & $9.50^{\mathrm{ab}}$ & $10.71^{\mathrm{b}-\mathrm{c}}$ & $15.50^{\mathrm{b}-\mathrm{d}}$ & $18.37^{\mathrm{a}-\mathrm{e}}$ \\
\hline Q & $0.00^{c}$ & $0.00^{\mathrm{d}}$ & $0.00^{\mathrm{b}}$ & $0.00^{\mathrm{c}}$ & $0.00^{\mathrm{d}}$ & $0.00^{f}$ \\
\hline $\mathrm{R}$ & $5.00^{a-c}$ & $2.56^{\mathrm{cd}}$ & $11.33^{\mathrm{ab}}$ & $6.72^{\mathrm{de}}$ & $17.5^{b c}$ & $6.72^{\mathrm{c}-\mathrm{f}}$ \\
\hline S & $4.33^{a-c}$ & $3.89^{b-d}$ & $4.33^{\mathrm{ab}}$ & $7.45^{\mathrm{c}-\mathrm{c}}$ & $4.33^{\mathrm{cd}}$ & $13.11^{\mathrm{a}-\mathrm{f}}$ \\
\hline $\mathrm{T}$ & $8.86^{a}$ & $5.92^{b-d}$ & $8.86^{\mathrm{ab}}$ & $5.92^{\mathrm{de}}$ & $8.86^{b-d}$ & $5.92^{c-f}$ \\
\hline $\mathrm{U}$ & $5.67^{a-c}$ & $5.78^{b-d}$ & $5.67^{\mathrm{ab}}$ & $13.64^{\mathrm{c}-\mathrm{c}}$ & $6.00^{b-d}$ & $15.97^{a-f}$ \\
\hline V & $0.00^{c}$ & $2.22^{\mathrm{cd}}$ & $4.33^{\mathrm{ab}}$ & $10.42^{b-c}$ & $6.67^{b-d}$ & $10.42^{b-f}$ \\
\hline W & $2.33^{a-c}$ & $8.89^{\mathrm{b}}$ & $8.00^{\mathrm{ab}}$ & $19.49^{a b}$ & $10.33^{\mathrm{b}-\mathrm{d}}$ & $25.82^{\mathrm{ab}}$ \\
\hline $\mathrm{X}$ & $7.00^{a-c}$ & $15.22^{\mathrm{a}}$ & $7.67^{\mathrm{ab}}$ & $28.82^{a}$ & $10.33^{b-d}$ & $29.15^{a}$ \\
\hline $\mathrm{Y}$ & $0.00^{c}$ & $2.22^{\mathrm{cd}}$ & $4.00^{\mathrm{ab}}$ & $2.20^{\mathrm{de}}$ & $6.50^{b-d}$ & $2.22^{\mathrm{ef}}$ \\
\hline Z & $0.00^{c}$ & $0.00^{\mathrm{d}}$ & $0.00^{\mathrm{b}}$ & $5.33^{\mathrm{de}}$ & $0.00^{\mathrm{d}}$ & $5.33^{\mathrm{d}-\mathrm{f}}$ \\
\hline
\end{tabular}

Values with the same letter(s) along the same column are not significantly different at $p=0.05$ 
126

Tab. 5. Number of Secondary roots from seedlings of scarified seeds of $P$. biglobosa samples

\begin{tabular}{cccc}
\hline Trees & $5 \mathrm{~min}$ & $10 \mathrm{~min}$ & $15 \mathrm{~min}$ \\
\hline C & $1.33^{\mathrm{a}-\mathrm{j}}$ & $4.50^{\mathrm{c}-\mathrm{i}}$ & $5.06^{\mathrm{c}-\mathrm{g}}$ \\
F & $3.17^{\mathrm{c}-\mathrm{j}}$ & $4.67^{\mathrm{c}-\mathrm{h}}$ & $4.06^{\mathrm{d}-\mathrm{i}}$ \\
G & $4.67^{\mathrm{c}-\mathrm{h}}$ & $7.58^{\mathrm{a}-\mathrm{d}}$ & $9.49^{\mathrm{ab}}$ \\
I & $7.55^{\mathrm{a}-\mathrm{d}}$ & $6.81^{\mathrm{a}-\mathrm{c}}$ & $9.66^{\mathrm{ab}}$ \\
J & $1.67^{\mathrm{a}-\mathrm{j}}$ & $4.50^{\mathrm{c}-\mathrm{j}}$ & $7.00^{\mathrm{a}-\mathrm{c}}$ \\
L & $9.66^{\mathrm{ab}}$ & $3.72^{\mathrm{d}-\mathrm{j}}$ & $8.52^{\mathrm{a}-\mathrm{c}}$ \\
Q & $6.33^{\mathrm{a}-\mathrm{c}}$ & $8.52^{\mathrm{a}-\mathrm{c}}$ & $9.80^{\mathrm{a}}$ \\
R & $6.11^{\mathrm{a}-\mathrm{c}}$ & $6.73^{\mathrm{a}-\mathrm{c}}$ & $9.12^{\mathrm{ab}}$ \\
S & $0.67^{\mathrm{ij}}$ & $5.13^{\mathrm{b}-\mathrm{f}}$ & $7.55^{\mathrm{a}-\mathrm{d}}$ \\
Y & $7.19^{\mathrm{a}-\mathrm{d}}$ & $7.03^{\mathrm{a}-\mathrm{c}}$ & $5.69^{\mathrm{b}-\mathrm{f}}$ \\
Z & $2.00^{\mathrm{f}-\mathrm{j}}$ & $0.00^{\mathrm{j}}$ & $1.00^{\mathrm{h}-\mathrm{j}}$ \\
\hline
\end{tabular}

Values with the same letter(s) along the same column are not significantly different at $p=0.05$

\section{Conclusions}

This study reveals that the seed germination and seedlings vegetative growth characteristics are different among the $P$. biglobosa populations. While some germination ready within 24 hours without pretreatment, some however requires pretreatment method of seed scarification with acid for varying period of time. The seeds from different Parkia populations respond differently to light effect. In general, seeds from various Parkia populations responded well to pretreatment and this is a very promising character in selecting this species of tree for possible reforestation programs and checking of desert encroachment, as it is one of the most economic trees in Africa.

\section{References}

Agboola DA, Adedire MO (1998). Response of treated dormant seeds of three species to germination promoters. Nig J Bot 11:103-109.

Agboola DA (1998). Dormancy and seed germination in some weeds lands. Nig J Bot 11:79-87.

Agboola DA, Etejere EO (1991). Studies on seed dormancy of selected economic tropical forest species. Nig J Bot 4:115125.

Akhter N, Rahman MM, Hasanuzzaman M, Nahar K (2009). Physiological Response of Garden Pea (Pisumsativum L.) Growth under Different Light Environment. Bot Res Internat 2(4):304-309.

Aliero BL (2004). Effects of sulphuric acid, mechanical scarification and wet heat treatments on the germination of seeds of Afican locust bean tree, Parkiabiglobosa. Afr J Biotech 3(3):179-181.

Andrews TS (1997). Factors affecting the germination of giant parramatta grass. Austr J Experim Agric 37:439-446.
Calvin M (1961). Quantum conversion of photosynthesis. J Theoret Biol 1:258.

Encyclopaedia Britannica (2011). Seed and Fruit. Retrieved from http://www.britannica.com/EBchecked/topic/532368/ seed.

Etejere EO, Fawole MO, Sanni A (1982). Study on the germination of P. clappertoniana. Nig J Bot (32):181-185.

Garcia FP, Pita JM, Benito MG, Iriondo JM (1995). Effect of light, temperature and seed priming on germination of celery seeds (Apiumgraveolens L). Seed Sci Technol 23:377-383.

Hall JB, Tomlinson HF, Oni PI, Buchy M, Aebischer DP (1997). ParkiaBiglobosa a Monograph. Bangor, UK: School of Agriculture and Forest, Sciences, University of Wales.

Hopkin B (1983). The taxonomy, reproductive biology and economic potentials of Parkia in Africa and Madagascar. Bot J Linnean Soc 87:135-167.

Huang SD, Ashely A Boerma HR (1993). Light intensity, row spacing and photoperiod effects on expression of brachytic stem in soybean. Crop Sci 33:29-37.

Khan MA, Rizvi Y (1994). Effect of salinity, temperature, and growth regulators on the germination and early seed growth of Atriplexgriffithii var. Canadian J Bot 27:475-479.

Khan MA, Ungar IA (1999). Alleviation of Seed Dormancy in the Desert Forb Zygophyllum simplex L. from Pakistan. Annals Bot 80:395-400.

Levitt J (1974). Introduction to plant physiology. C.V. Mosby Company U.S.A, 277-286 p.

Nikoleave MG (1977). Factors controlling seed dormancy pattern. NorthHolland publishing Co, Amsterdam, 51-74 p.

Olorunmaiye KS, Fatoba PO, Imeh-Nathaniel A (2004). Effects of seed coat removal on seed germination and seedling development in Afzelia Africana Sm. NISEB Journal 4(1):5-9.

Olorunmaiye KS, Fatoba PO, Adeyemi CO, Olorunmaiye PM (2011). Fruit and Seed characteristics among selected Parkiabiglobosa (JACQ) G. Don. Population. Agric Biol J North America 2(2):244-249

Sabongari S (2001). Effect of Soaking duration on germination and seedling establishment of selected varieties of Tomato (Lycopersicumesculentum Mill). M. Sc. Thesis, Department of Biology Sciences, UsmanuDanfodiyo University Sokoto, Nigeria.

Sacande M, Clethero C (2007). Parkiabiglobosa (Jacq.) G. Don. Millennium Seed Bank Project Kew. Seed Leaflet No 124.

Singh S (1997). Growth and yield response of different crop species to low light and high temperature-humidity stress. Indian J Plant Physiol 2:151-155. 